\title{
Simulation based study of Maximum Power Point Tracking and Frequency Regulation for Stand-alone Solar Photovoltaic Systems
}

\author{
M. A. Islam ${ }^{1}$, A. Merabet ${ }^{1}$, R. Beguenane ${ }^{2}$, H. Ibrahim ${ }^{3}$ and H. Ahmed ${ }^{4}$ \\ ${ }^{1}$ Division of Engineering \\ Saint Mary's University \\ 923 Robie Street, Halifax, NS, B3H 3C3 Canada \\ Phone number: +1 (902) 420-5101, e-mail: md.aminul@ smu.ca, adel.merabet@smu.ca \\ ${ }^{2}$ Royal Military College, Kingston, ON, Canada \\ ${ }^{3}$ Wind Energy Techno-Centre, Gaspe, QC, Canada \\ ${ }^{4}$ Non-A Team, INRIA Lille-Nord Europe, Lille, France
}

\begin{abstract}
The main objective of this paper is to develop a simulation model of stand-alone solar photovoltaic (PV) system based on mathematical models. A maximum power point tracking (MPPT) algorithm based on incremental conductance method is applied to extract the maximum power from solar PV energy conversion system. A DC/DC boost converter allows the MPPT to control the intermediate voltage. To regulate to voltage at load side a voltage source converter (VSC) based controller is applied to generate the pulse signal for three-phase inverter. The frequency regulation controller is developed based on conventional phase locked loop (PLL) system along with resistive dumping loads. A simulation model based on mathematical model is constructed using Matlab ${ }^{\circledR} /$ Simulink $^{\circledR} /$ SimPower $^{\circledR}$ interface. Results from simulation are stated to demonstrate the behaviour of standalone solar PV energy conversion system.
\end{abstract}

\section{Key words}

Solar photovoltaic cell, MPPT, frequency regulation, VSC control, stand-alone system

\section{Introduction}

The development of renewable energy sources has attracted a lot of attention from both the research and industrial community since last few decades. This attention is mainly due to the energy crisis like volatility of the oil market and also because of the various environmental issues such as global warming \& pollution etc. Out of various renewable energy sources, some of them noticed a tremendous growth in the last few decades especially because of their potentiality. Renewable energy sources like Combined Heat \& Power (CHP), solar photovoltaic (PV) module, small wind turbine, energy and heat storage are few of the such potential areas where controllable loads are supposed to play a great role for the future electricity supply [1].
Out of many potential renewable energy sources, PV technology clearly distinguished itself from the others because of its popularity. However the wide spread growth of PV technology gives rise to many technical questions like the optimal extraction of the solar power from PV panel, controlling the load frequency when PV panel is used as an energy source in micro-grid etc. These questions need to be addressed to progress further in the research of PV technology. A lot of research has already been made in order to address the above mentioned points. The first point is how it can be made possible to extract the maximum power from the PV panel. The PV array power and current characteristics are highly nonlinear and are affected by the irradiance and temperature variation. Therefore, a maximum power-point tracker (MPPT) is required to handle such problems and to ensure that the PV system is operating at the Maximum Power Point (MPP) [1], [2]. The research on MPPT technique is a very active research area and a lot of contributions regarding this area have already been made. In [3], a comparative study on the maximum power point techniques for the photovoltaic power systems is presented. The difference between the various MPPT techniques lies in simplicity, accuracy, time response, popularity, cost and other technical aspects. Popular MPPT techniques include Perturb \& Observe (P\&O), Incremental Conductance, hill climbing etc. Their popularity lies in their simplicity, ease of implementation and low cost.

The second point that comes while supplying the load through PV power is the load frequency regulation in the PV connected micro-grid. This problem arises due to the intermittent nature of the photovoltaic power generation. As PV power depends on the irradiation and temperature, the output power is not constant. So, when the output power increase/decreases with respect to the load demand, the frequency starts to deviate from the desired frequency. 
This creates the problem of frequency regulation. Various approaches have already been taken to terminate this problem. An energy storage technique is used in [3] to regulate the load frequency due to sudden change in demand and supply. In [4], energy storage is used to reduce the impact of wind and solar generation by the means of dynamic frequency control through the energy storage. The application of dump load based dynamic frequency regulation for the case of small hydro power plant based micro-grid is discussed in [5].

In this paper, a simulation based study is demonstrated for the case of stand-alone solar photovoltaic system. At first, a detailed mathematical model of the solar panel is developed from the equivalent circuit or solar cell. Then, incremental conductance based MPPT algorithm is applied to operate the system at maximum power point and this was done through the power electronic interface. Finally, dump load based frequency regulation approach was used to control the load frequency due to the change in load and supply.

\section{Modeling Solar PV Cell and Array}

\section{A. Modeling Solar PV Cell, Module and Array:}

To generate the behaviour of solar photovoltaic (PV) cell a simulation model is constructed based on mathematical model. A mathematical expression of load current can be obtained from the equivalent circuit of a solar PV cell. The equivalent circuit of a solar PV cell can be expressed like following [6], [7];

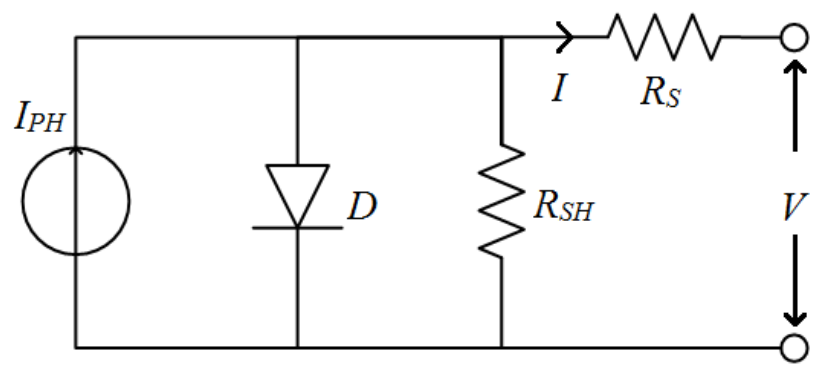

Fig. 1. Equivalent circuit of solar photovoltaic cell

The load current equation from this equivalent circuit is given below [8];

$$
I=I_{P H}-I_{S}\left[\exp \frac{q\left(V+I R_{S}\right)}{N K T}-1\right]-\frac{\left(V+I R_{S}\right)}{R_{S H}}
$$

In this equation, $I$ is load current, $I_{P H}$ is photocurrent, $I_{S}$ is diode saturation current, $q$ is electron charge, $V$ is the cell terminal voltage, $N$ is diode ideality factor, $K$ is the Boltzmann constant, $T$ is cell temperature, $R_{S}$ and $R_{S H}$ is the series and shunt resistance respectively.

In order to develop a simulation model of $6 \mathrm{~kW}$ solar PV array a 250W PV module CS6P-250M manufactured by 'Canadian Solar' has been considered as standard [9]. Following table shows required key specification of the PV module under standard test condition (STC):
Table I. -Key specification of CS6P-250M PV module under STC

\begin{tabular}{|l|c|}
\hline \multicolumn{1}{|c|}{ ELECTRICAL CHARATERISTICS } & CS6P-250M \\
\hline Nominal Maximum Power & $250 \mathrm{~W}$ \\
\hline Optimum Operating Voltage & $30.4 \mathrm{~V}$ \\
\hline Optimum Operating Current & $8.22 \mathrm{~A}$ \\
\hline Open Circuit Voltage, $\mathrm{V}_{\mathrm{OC}}$ & $37.5 \mathrm{~V}$ \\
\hline Short Circuit Current, $\mathrm{I}_{\mathrm{SC}}$ & $8.74 \mathrm{~A}$ \\
\hline Temperature Coefficient of $\mathrm{I}_{\mathrm{SC}}, \mathrm{K}_{\mathrm{i}}$ & $0.005 \mathrm{~A} /{ }^{\circ} \mathrm{C}$ \\
\hline
\end{tabular}

The original PV module contains total 60 cells. In order to generate the specified voltage from the simulated model total 60 cells are required to connect in series. In this model desired voltage level is achieved by applying a gain on the cell voltage, equals to the number of total cells, to develop the model of a $250 \mathrm{~W}$ PV module.

A total number to $24 \mathrm{PV}$ modules are connected in series and parallel to generate $6 \mathrm{~kW}$ power. In this model $4 \mathrm{PV}$ modules are connected in parallel to create a bank with $120 \mathrm{~V}$. Such 6 banks of PV module are connected in series to meet the desired amount of total $6 \mathrm{~kW}$ power.

\section{B. Effect of Varying Solar Irradiation:}

Photocurrent, $I_{P H}$ depends on solar irradiance and cell temperature. The output of PV module varies as a function of solar irradiance which can be obtained from the equation of photocurrent [7]-[8], [10];

$$
\mathrm{I}_{\mathrm{PH}}=\left[\mathrm{I}_{\mathrm{SC}}+\mathrm{K}_{\mathrm{i}}\left(\mathrm{T}-\mathrm{T}_{\mathrm{ref}}\right)\right] \frac{\mathrm{B}}{1000}
$$

Here, $I_{S C}$ is short circuit current, $K_{i}$ is temperature coefficient of short circuit current, $T$ is cell temperature, $T_{r e f}$ is reference temperature and $B$ is solar irradiance in $\mathrm{W} / \mathrm{m}^{2}$.

\section{Effect of Varying Temperature:}

Diode saturation current varies as a cubic function of cell temperature and it can be obtained from following equation [11];

$$
I_{S}(T)=I_{R S}\left(\frac{T}{T_{\text {ref }}}\right)^{\frac{3}{N}} e^{-\frac{q v_{t}}{N K\left(\frac{1}{T}-\frac{1}{T_{\text {ref }}}\right)}}
$$

In this equation, $I_{R S}$ is diode reverse saturation current and $V_{t}$ is thermal voltage. The diode reverse saturation current can be obtained from the equation given below [12];

$$
\mathrm{I}_{\mathrm{RS}}=\frac{\mathrm{I}_{\mathrm{SC}}}{\left[\mathrm{e}^{\mathrm{qV} \mathrm{OC} / \mathrm{NKT}}\right]}
$$

This model shows the effect of varying series and shunt resistance since equation (1) is dependent of the parameter $R_{S}$ and $R_{S H}$.

\section{Maximum Power Point Tracking}

To operate the solar PV system in maximum power extraction a maximum power point tracking (MPPT) algorithm is applied. MPPT strategy ensures the 
maximum power extraction from non-linear resources like solar PV system. It allows the controller to operate the PV module at optimum voltage and current. There are many methods for maximum power point tracking. Most common methods for solar PV systems are [13]-[15]:

\section{i. Constant voltage method \\ ii. Perturb and Observe (P\&O) method and \\ iii. Incremental conductance method etc.}

Among several MPPT algorithms incremental conductance method is recommended due to higher accuracy and reliability [13]-[15]. This method estimates the relation between the operating voltage $U$ and maximum voltage $U_{\max }$ [16]. Method of increasing conductivity follows three conditions: $U<U_{\max }, U>U_{\max }$ and $U=U_{\max }$. To realize the maximum power point (MPP) a reference voltage, $U_{\text {ref }}$ is applied. When the solar irradiance and outside temperature changes, the incremental conductance method controls the output voltage to track the maximum power point voltage smoothly and also reduces the oscillation phenomenon near the MPP. The method can be expressed like following;

$$
\begin{gathered}
\frac{\mathrm{dI}}{\mathrm{dU}}=-\frac{\mathrm{I}}{\mathrm{U}} ;\left(\frac{\mathrm{dP}}{\mathrm{dU}}=0\right) \text { at MPP thus } U=U_{\max } \\
\frac{\mathrm{dI}}{\mathrm{dU}}>-\frac{\mathrm{I}}{\mathrm{U}} ;\left(\frac{\mathrm{dP}}{\mathrm{dU}}>0\right) \text { left of MPP thus } U<U_{\max } \\
\frac{\mathrm{dI}}{\mathrm{dU}}<-\frac{\mathrm{I}}{\mathrm{U}} ;\left(\frac{\mathrm{dP}}{\mathrm{dU}}<0\right) \text { right of MPP thus } U>U_{\max }
\end{gathered}
$$

However, this control method is complicated and the setting of adjusting voltage $\Delta U$ influences the maximum power point tracking accuracy greatly.

\section{Power Electronic Interface}

The form of electrical power generated from solar PV is DC electricity. A classic DC/DC boost converter is applied to regulate the DC link voltage. MPPT controller generates duty cycle in order to create switching signals for the converter. The switching signal allows the boost converter to operate the solar PV system at optimum voltage and current so that the maximum power extraction is possible. Induced voltage at the output end of solar PV array is $120 \mathrm{~V}$. The DC/DC converter boosts the voltage close to $600 \mathrm{~V}$ to meet the required voltage at system bus.

A DC/AC three phase inverter is applied to connect the system with AC loads. To regulate the voltage at load side a voltage source converter (VSC) based controller is applied. It requires $a b c$ to $d q$ transformation (Park's transformation) and consists of proportional integral (PI) controller. The output of PI controller is again transformed from $d q$ to $a b c$ and afterwards 6 pulse width modulation (PWM) switching signals are generated to regulate the voltage through the inverter. Construction of the controller for voltage regulation is like following:

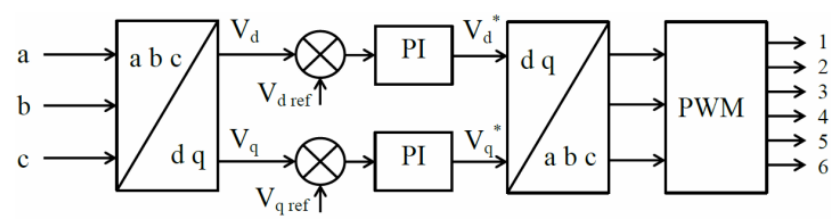

Fig. 2. Voltage regulator for three phase inverter

A schematic diagram of stand-alone solar photovoltaic system is given below.

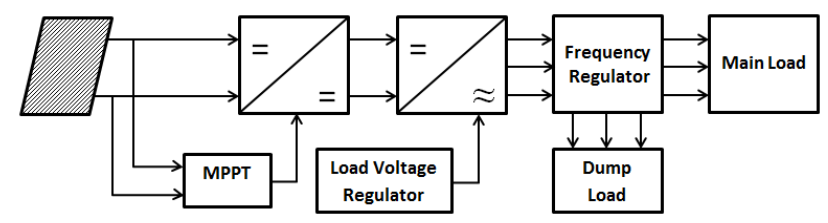

Fig. 3. Schematic diagram of stand-alone solar PV system

\section{Frequency Regulation}

The frequency regulation strategy is developed with a set of resistive dump load when a total of $3.5 \mathrm{~kW}$ resistive main load is connected to the system. Total 8 sets of resistive dump load are used regulated the frequency in case of over generated electricity and each set consumes $0.5 \mathrm{~W}$. Maximum power consumed by the dump loads in this system is $4 \mathrm{~kW}$. Each set of resistive load is added in operation gradually depending on generated power and load demand.

According to the North-American standard frequency is kept constant at $60 \mathrm{~Hz}$. The controller for frequency regulator is developed with a conventional three-phase locked loop (PLL) control strategy. It allows the system to operate at constant frequency of $60 \mathrm{~Hz}$ and synchronizes the operation between source and load side components.

\section{Simulation and Results}

The developed model is executed using Matlab $^{\circledR} /$ Simulink $^{\circledR} /$ SimPower $^{\circledR}$ simulation interface and the generated results are given below. This simulation was executed for 10 seconds with variable solar irradiance and under standard test condition (STC) where cell temperature is $25^{\circ} \mathrm{C}$.

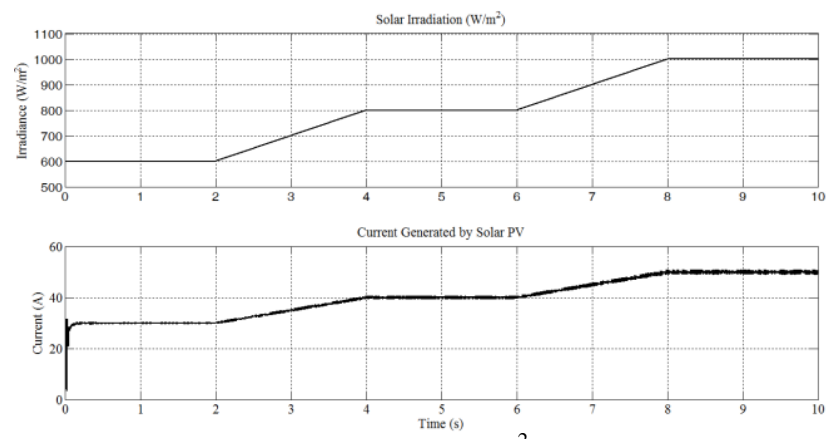

Fig. 4. Variable solar irradiation $\left(\mathrm{W} / \mathrm{m}^{2}\right)$ and current generated by solar PV 

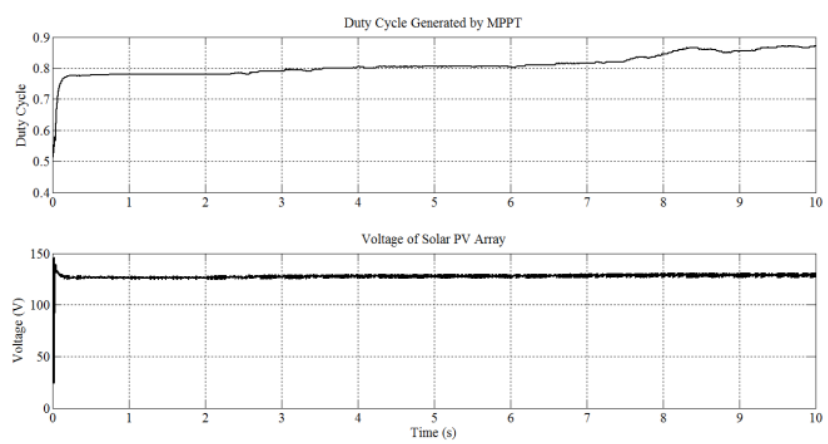

Fig. 5. Duty cycle generated by MPPT and voltage induced by solar PV array
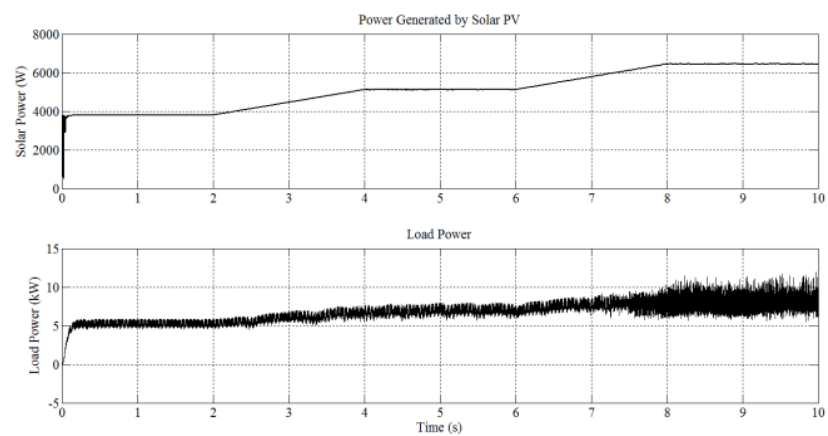

Fig. 6. Power generated by solar PV (W) and load power (kW)
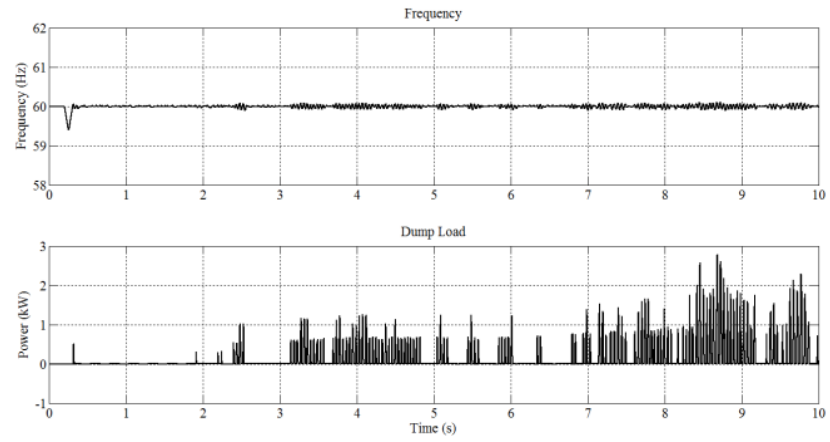

Fig. 7. Frequency of the system and dump load actions

Fig. 4 shows the variable solar irradiance applied to the system and generated current following the variation of irradiation. In this simulation irradiation varies from 600 to $1000 \mathrm{~W} / \mathrm{m}^{2}$. Generated current varies in a limit from $30 \mathrm{~A}$ to $50 \mathrm{~A}$ approximately depending on solar irradiation.

Incremental conductance method based MPPT controller calculates proper duty cycle to generate switching pulse signals for the DC/DC boost converter. Fig. 5 states the duty cycle and voltage induced at solar PV array.

Total power generated by solar PV and the power consumed by resistive load is plotted in fig. 6 . The regulation of frequency and resistive dump load actions are stated in fig. 7.

\section{Conclusion}

This paper describes a mathematical and simulation model of stand-alone solar PV energy conversion system. A simulation model is developed to study the behaviour of stand-alone solar photovoltaic system. Maximum power point tracking algorithm is applied to operate the system at optimum level. A DC/DC boost converter and
DC/AC three-phase inverter connects the system with resistive main load. Load voltage is regulated with a VSC controller. Simple frequency regulation method based on traditional three-phase locked loop (PLL) is proposed with resistive dump load. Since the use of resistive dump load for frequency regulation is not recommended, further continuation of this work may replace the mode of operation with energy storage.

\section{Acknowledgement}

This work is supported by the Faculty of Graduate Studies and Research at Saint Mary's University, Halifax, NS and Royal Military College, Kingston, ON.

\section{References}

[1] B. N. Alajmi, K. H. Ahmed, S. J. Finney and B. W. Williams, "Fuzzy-Logic-Control Approach of a Modified Hill-Climbing Method for Maximum Power Point in Microgrid Standalone Photovoltaic System," Power Electronics, IEEE Transactions on , vol. 26, no. 4, pp. 1022,1030, April 2011.

[2] C. Hua, J. Lin and C. Shen, "Implementation of a DSPcontrolled photovoltaic system with peak power tracking," Ind. Electron., IEEE Transaction on, vol. 45, no. 1, pp. 99107, Feb. 1998.

[3] D. C. Das, A.K. Roy and N. Sinha, "GA based frequency controller for solar thermal-diesel-wind hybrid energy generation/energy storage system," International Journal of Electrical Power \& Energy Systems, vol. 43, no. 1, pp. 262279, Dec. 2012.

[4] G. Delille, B. Francois and G. Malarange, "Dynamic Frequency Control Support by Energy Storage to Reduce the Impact of Wind and Solar Generation on Isolated Power System's Inertia," Sustainable Energy, IEEE Transactions on , vol. 3, no. 4, pp. 931-939, Oct. 2012.

[5] S. Doolla, and T. S. Bhatti, "Load Frequency Control of an Isolated Small-Hydro Power Plant With Reduced Dump Load," Power Systems, IEEE Transactions on , vol. 21, no. 4, pp. 1912-1919, Nov. 2006.

[6] W. Chen, H.Shen, B. Shu, H. Qin and T. Deng, "Evaluation of performance of MPPT devices in PV systems with storage batteries," Renewable Energy, vol. 32, no. 9, pp. 1611-1622, July 2007.

[7] T. Salmi, M. Bouzguenda, A. Gastli and A. Masmoudi, "Matlab/Simulink based modeling of solar photovoltaic cell," International Journal of Renewable Energy Research, vol. 2, no. 2, pp. 213-218, Feb. 2012.

[8] M. A. Islam, A. Merabet, R. Beguenane and H. Ibrahim, "Modeling Solar Photovoltaic Cell and Simulated Performance Analysis of a 250W PV Module," IEEE Electrical Power \& Energy Conference, pp. 1-6, Aug. 2013.

[9] Canadian Solar, "CS6P 240/245/250/255/260M," CS6P250M Datasheet, 2013. [Online]. Available: http://www.canadian-solar.com

[10] I. V. Banuand and M. Istrate,"Modeling and simulation of photovoltaic arrays," Buletinul AGIR, vol. 3, pp. 161-166, Aug. 2012.

[11] S. Said, A. Massoud, M. Benammar, and S. Ahmed. "A Matlab/Simulink based photovoltaic array model employing SimPower Systems Toolbox," Journal of Energy and Power Engineering, vol. 6, pp. 1965-1975, Dec. 2012.

[12] T. Bennett, A. Zilouchian and R. Messenger, "Photovoltaic model and converter topology considerations for MPPT purposes," Solar Energy, vol. 86, no. 7, pp. 2029-2040, July 2012. 
[13] C. S. Chiu, Y. L. Ouyang and C. Y. Ku., "Terminal sliding mode control for maximum power point tracking of photovoltaic power generation systems," Solar Energy, vol. 86, no. 10, Oct. 2012.

[14] S. Kebaili and A. Betka, "Design and simulation of stand alone photovoltaic systems," WSEAS Transactions on Power Systems, vol. 6, no. 4, pp. 89-99, Oct. 2011.
[15] D. P. Hohm and M. E. Ropp. "Comparative study of maximum power point tracking algorithms," Progress in Photovoltaics: Research and Applications, vol. 11, pp. 4762, 2003.

[16] L. Qin and X. Lu., "Matlab/Simulink-based Research on Maximum Power Point Tracking of Photovoltaic Generation,'Physics Procedia, vol. 24, pp. 10-18, 2012. 